University of Nebraska - Lincoln

DigitalCommons@University of Nebraska - Lincoln

$11-1-2003$

\title{
A Macrokinetic Study of the High-Temperature Solid-Phase Titanium-Carbon Reaction
}

Julia Y. Kostagorva

Department of Chemical Engineering, University of Nenraska-Lincoln

Hendrik J. Viljoen

University of Nebraska-Lincoln, hviljoen1@unl.edu

Alexander S. Shteinberg

ALOFT corporation, Berkely, California, 94708.

Follow this and additional works at: https://digitalcommons.unl.edu/chemengreaction

Part of the Chemical Engineering Commons

Kostagorva, Julia Y.; Viljoen, Hendrik J.; and Shteinberg, Alexander S., "A Macrokinetic Study of the HighTemperature Solid-Phase Titanium-Carbon Reaction" (2003). Papers in Reaction Kinetics. 2.

https://digitalcommons.unl.edu/chemengreaction/2

This Article is brought to you for free and open access by the Chemical and Biomolecular Engineering Research and Publications at DigitalCommons@University of Nebraska - Lincoln. It has been accepted for inclusion in Papers in Reaction Kinetics by an authorized administrator of DigitalCommons@University of Nebraska - Lincoln. 


\title{
A Macrokinetic Study of the High-Temperature Solid- Phase Titanium-Carbon Reaction
}

\author{
Julia Y. Kostogorova and Hendrik J. Viljoen \\ Department of Chemical Engineering, University of Nebraska, Lincoln, Nebraska 68588
}

\author{
Alexander S. Shteinberg \\ ALOFT Corporation, Berkeley, California 94708
}

An experimental method, electro thermal explosion (ETE), is used to measure the macro kinetic parameters of the high-temperature titanium/carbon reaction. Different stages of the reaction have been identified, but the focus of this study is on the reaction between solid titanium and solid carbon, i.e., prior to the melting of titanium. The reaction has high activation energy, and an electric current is used to heat the cylindrically shaped sample to a specified temperature. The current is shut off at a temperature below the melting point of titanium; any further temperature rise is only due to reaction. The output of the ETE equipment is temperature time data that can be processed to recover the kinetic parameters. The activation energy and preexponential factor of the reaction rate constant are calculated and comprise $214 \mathrm{~kJ}$ mol-1 and $(6.2$ ( 1.5$) \_107 \mathrm{~s}-1$, respectively. An important aspect of solid-phase reactions is the contact area between reactants. The contact area between titanium and carbon particles is calculated, and the reaction constant is corrected for this effect.

Published in Industrial and Engineering Chemistry Research 2003, Vol. 42 No 26, 6714-6719

(C) 2003 American Chemical Society:

Web Release Date: November 20, 2003

The American Chemical Society allows the posting of only the title, abstract, tables, and figures from articles appearing in the Journal of American Chemical Society.

This article can be viewd at the publishers site:

http://pubs.acs.org/cgi-bin/abstract.cgi/iecred/2003/42/i26/abs/ie030337k.html

DOI: 10.1021/ie030337k Copyright $@ 2003$ American Chemical Society. 
Figuwe 1. Schenatic of ETE equiprnent.
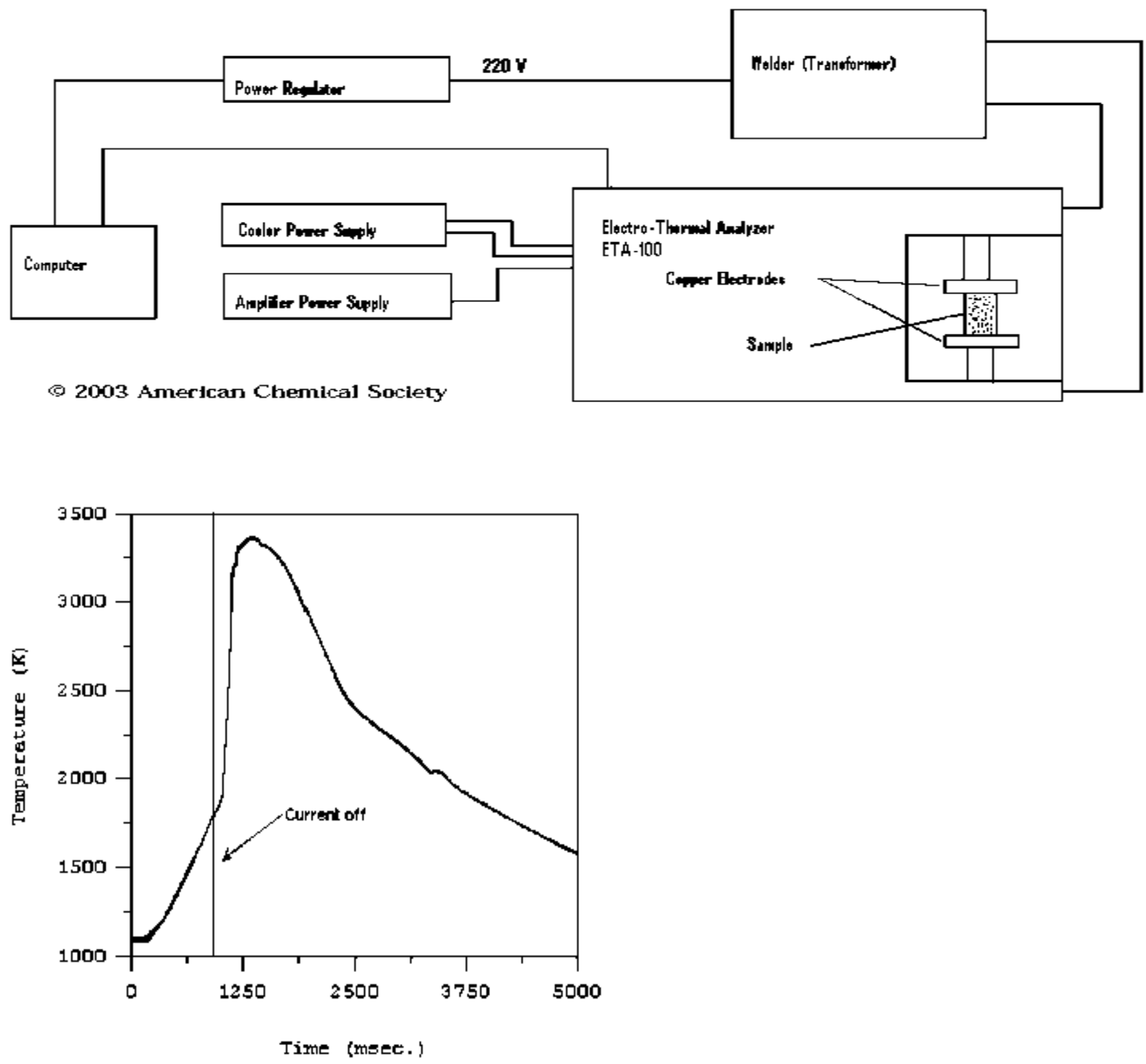

Figure 2. Experlmental data of temperature laveraged over channels 9 and 10 ) vs time.

9 2003 American Chemical Soclety

A Macrokinetic Study of the High-Temperature Solid-Phase Titanium-Carbon Reaction Julia Y. Kostogorova, Hendrik J. Viljoen, Alexander S. Shteinberg 
Figure 3. Conversion vs time.

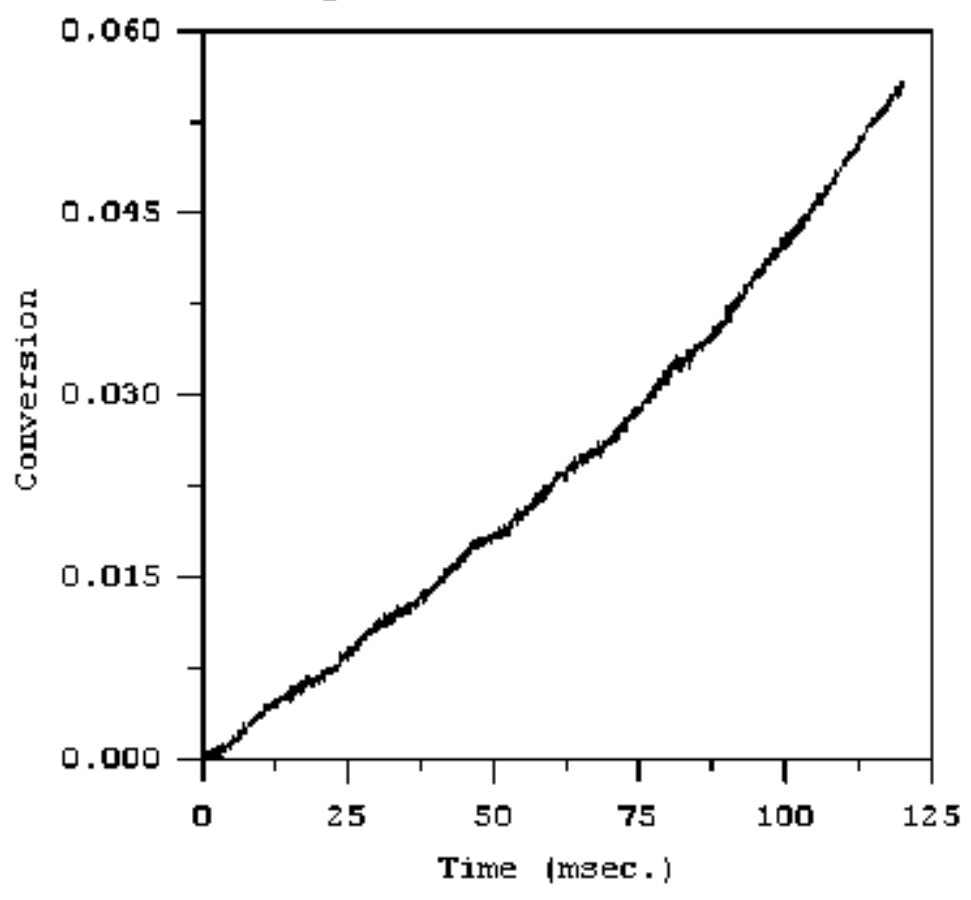

62003 American Chemical Soclety

Figure 4. Arrhendus dependence.

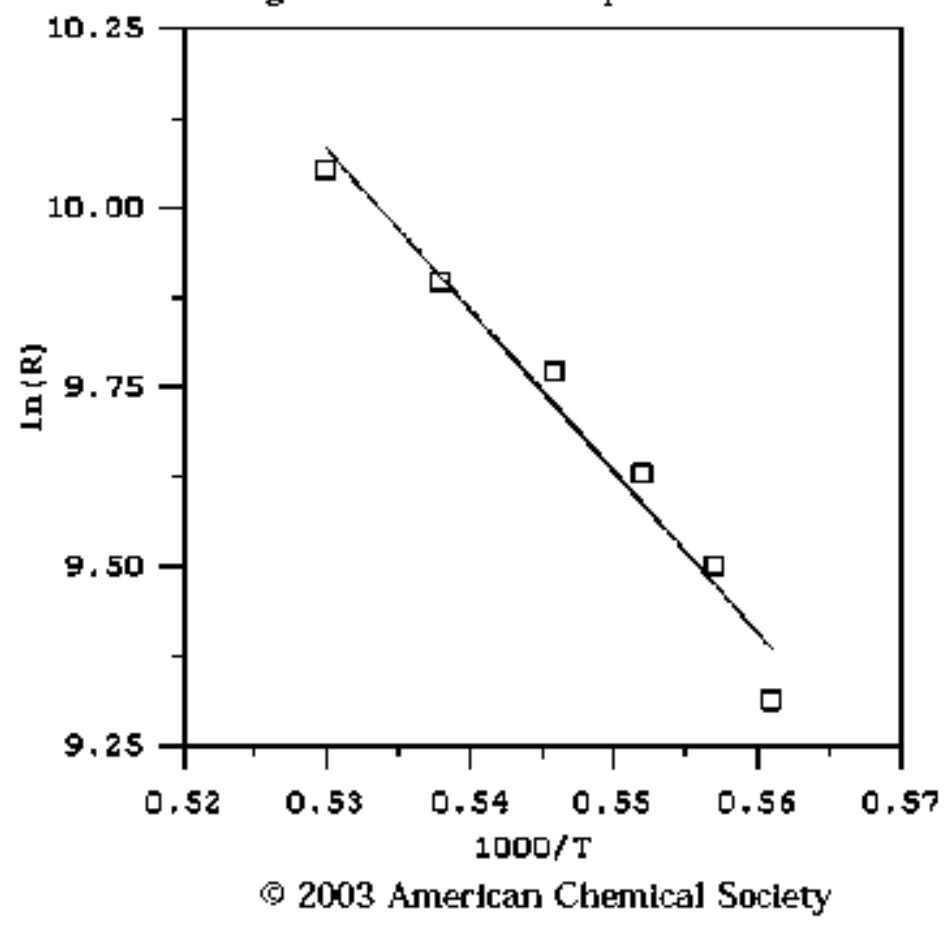

A Macrokinetic Study of the High-Temperature Solid-Phase Titanium-Carbon Reaction Julia Y. Kostogorova, Hendrik J. Viljoen, Alexander S. Shteinberg 
Figure 5. Adsorption 1sotherm for titarium powder, $44 \mu \mathrm{m}$.

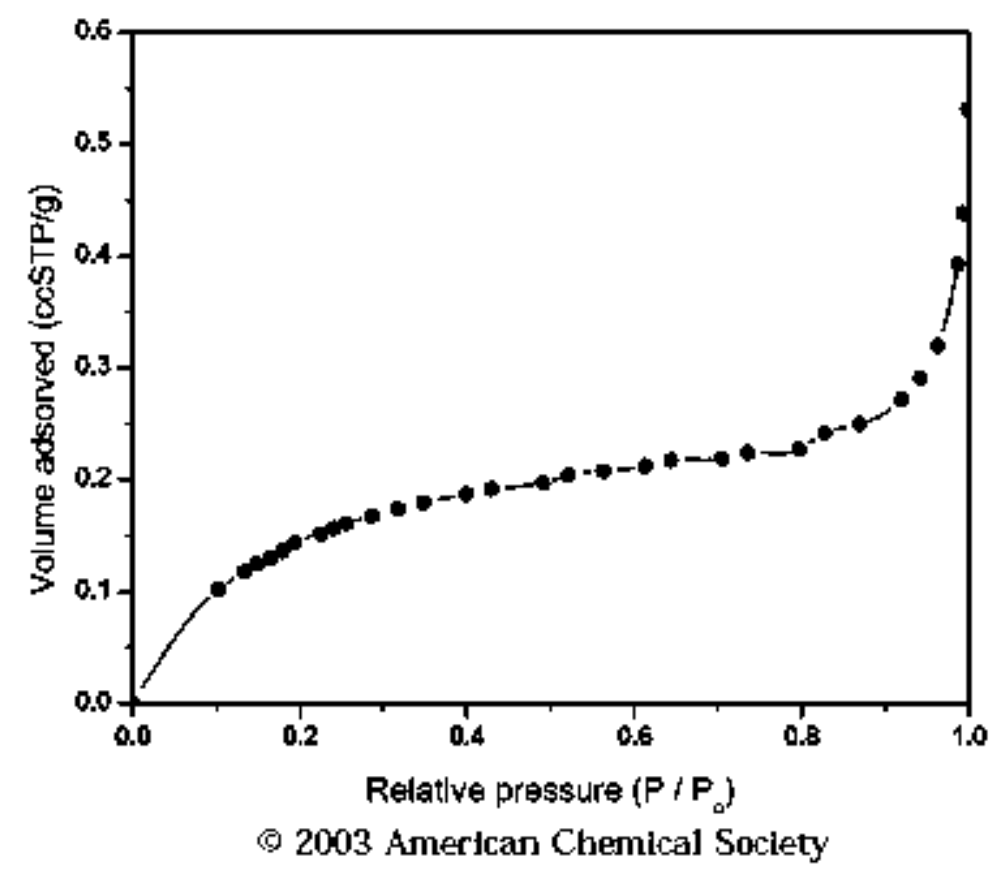

Figure 6. Adsorption 15otherm for carbon powder, $44 \mu \mathrm{m}$.

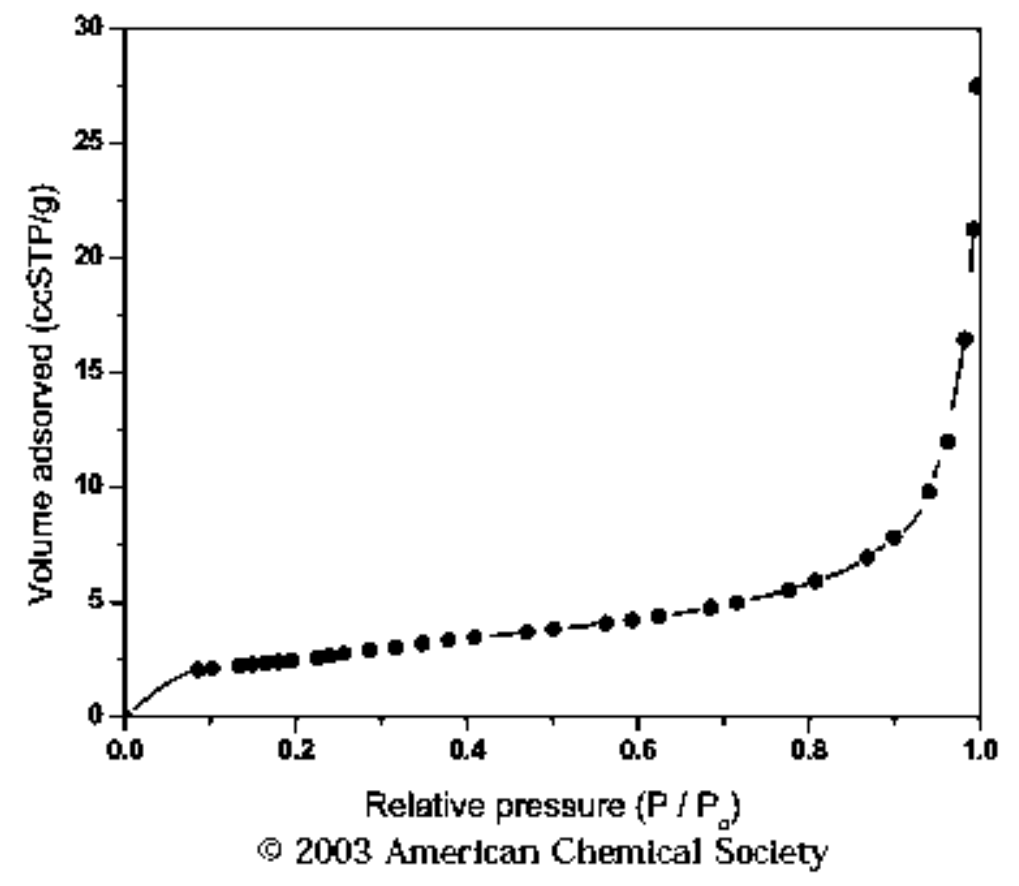

